\title{
A Path to a Green Future
}

\author{
Ishaan Bharadwaj
}

\begin{abstract}
The role of programs like Eco Ambassadors is to encourage interest in the environment early on in life. Children become aware of the environmental problems that the world is facing.

My story is about how this program has developed my eco-friendly self, and the activities I have done that helped me to discover my passion for environmental science and to understand all the interactions between our environment and people. I started these activities a year ago, when I was 10, and the program introduced me to new ideas and has challenged me to explore and experiment with different thoughts. Through this journey, I showed my friends, family, and community how these environmental issues could be solved if everyone works together.

I believe that if children get exposed to such programs and activities, they will become eco-friendly and take the initiative to protect and preserve the environment.
\end{abstract}

\section{Keywords}

education for sustainable development - Eco Ambassadors - community environment

\section{Reuse School Supplies, Join Eco Ambassadors}

It was the end of the summer break in August 2019. I was getting ready to go to middle school in a few weeks. As I was preparing to get the school supplies and making a list, my parents looked at the unused supplies from the year before and suggested that I reuse them. At first, I was not so thrilled about the idea, but then I thought about it. Why can't I reuse them? If I don't use them every year, they will go to the landfill. So would all the unused supplies from all the other kids. Therefore, I decided that I would reuse my school supplies and try to collect and recycle supplies from other kids, too. And that's how School Tools to Go was born.

(C) UNESCO IBE, 2021 | DOI: 10.1163/9789004471818_016

This is an open access chapter distributed under the terms of the CC BY 4.0 License. 
At the same time, I got introduced to the Eco Ambassadors program through a community platform. The Eco Ambassadors program was started by the Center for Sustainable Development within the Earth Institute at Columbia University. It means to engage the next-generation youth in all places, so that they can begin educating their own communities about local environmental issues and start taking small steps toward solving these issues with community action. ${ }^{1}$ I was excited that now I could work and share ideas with kids my age on environment-friendly activities.

I got a perfect opportunity to talk about my school-supplies initiative on Climate Action Day, which was organized as part of the Fridays for Future movement initiated by Greta Thunberg. ${ }^{2}$ My school even allowed students to leave and participate in this event. Several students joined in the walk from our school to the local park center, holding posters to draw public attention to plastic pollution. I gave my first speech here, explaining my project of collecting gently used school supplies and donating them where they might be needed. I set up my first collection drive for School Tools to Go at this event, and I was surprised that I got a huge collection of school supplies, which I will be donating to less-well-supplied schools. The idea is that by reusing school supplies, we are reducing plastic waste and reducing the amount of material that goes into the oceans and landfills. This was my first experience with community engagement, and I got a very positive response. However, I do realize that the people who attended were already aware and ecoliterate.

After that, my family and I had an Eco Ambassador holiday challenge: to plan an activity to reduce plastic waste. We decided to host an eco-friendly Thanksgiving dinner at home. We took out all of our glassware, metal spoons, metal forks, and glass cups. We cooked everything at home, and we asked our guests to bring food without plastic packaging as well. We even crowned the most eco-friendly guest as either Eco King or Eco Queen of the day. I think our challenge helped our guests to become aware of the plastic problem and to become cautious about using plastic in their everyday lives. Our trash bag weighed almost nothing at the end of dinner!

\section{Single-Use Plastics Ordinance}

A few weeks later, the Eco Ambassadors were invited to speak at the municipal town hall to support an ordinance to ban single-use plastic items. Several of us, along with community members, spoke in front of the mayor and township committee. I talked about how we should ban single-use plastic bags, 
ban Styrofoam carryout containers, and call for providing straws only upon request. The ordinance passed with full votes. It went into effect June 12, 2020. This was a moment of realization for me, because I saw how different organizations, such as the local green team, the Boy Scouts, the school peer leaders, and individuals who were working independently at their own level, came together to bring about a significant change.

At one Eco Ambassadors event, I got introduced to microplastics by a Columbia University student who spoke at my local park center. She talked about microfibers, and how a significant quantity goes into the environment when clothes are washed in the washing machine. I was curious, and I wanted to find out more about where else microplastics can be found in our daily lives. I wanted to research this topic and present it in a regional science fair.

The science fair is a great opportunity for students to explore their areas of interest and to share ideas outside of school. I approached the college student who had introduced me to microplastics to help me and be my mentor. I wanted to know if New Jersey tap water had microplastics. She guided me through the process of conducting the experiment. My parents helped by driving me to 13 counties in New Jersey to collect tap water from various stores and homes. With the guidance of my mentor and the help of my parents, I built an apparatus (water filtration system), from scratch with scrap materials from my house. I learned how to do this by watching videos and images that my mentor suggested. I used this apparatus to filter the microplastics out of the sample water and quantified the amount of microplastics in each sample. What I found was shocking! There were microplastics in all samples, and those from some counties contained significantly large numbers compared to other. Even the tap water sourced from groundwater contained microplastics.

The next step in my research would be to collect and quantify the data for the rest of the counties in my state, a step I couldn't complete because of Covid19. I would also like to further expand my research, with more data, so that I can convince the water treatment plants to add another device to their original filtration systems, one that can filter out microplastics. Using my data, I want to create awareness in people about this significant problem and get them to understand that the plastic they use can end up in their own drinking water.

I want to share my findings with my peers, my teachers, and my community. But there are obstacles. First of all, not a lot of people know what microplastics are. Second, even if they know, not many understand how big a problem they 
pose to the environment. I feel people need to be more aware and connected to the environment to even understand the problem. This awareness needs to start at home and at school.

Later, I got an opportunity through the Eco Ambassadors program to speak at Columbia University about my microplastic research. My audience included graduate students and professors. The audience was interested in my research with microplastics. I recently conducted a webinar, educating Eco Ambassadors across the world about my research into microplastics.

At a personal level, getting this opportunity to work with a mentor was a great experience, as I got to learn from her how to conduct an experiment, follow through with the scientific procedures, analyze data, and come up with conclusions. The only reason I could do this project at a young age was because I had some access to a lab and an experienced mentor who could guide me through the whole process. More students would be willing to do such environmental projects if they had easy access to a lab and a guide-mentor-teacher. To encourage students to do different and unique projects to solve environmental problems, schools would do well to invest in the right types of lab equipment and other resources.

So far, I have done these activities with the support of a few community members, and only outside of my school. I feel that if schools were to get involved with such initiatives, the kids in the school would also work toward becoming eco-friendly. I believe that the school curriculum should include environmental education as a subject from $\mathrm{K}$ through 12 , which would result in daily or weekly reinforcement of the topics. Young children would then be exposed early on to the environmental problems that we face today. They would grow up to be eco-friendly and would take initiative in protecting and preserving the environment. Making "friendliness to the environment" part of the curriculum would ensure that it is not an option, but a requirement, for students to be ecoaware. Younger kids are more adaptable and can accept change easily. This is one way schools can help educate students who will become ambassadors to create a greener future.

Another way schools can help is to introduce programs initiated by student leaders. The peer leader program in my school introduces new ideas and clubs to the school. Only $20 \%$ of the students who apply get in, chosen for their passion and personalities as potential role models and leaders. The peer leader program is a perfect platform through which to present ideas to the governing 
adult school committee, because the students in this program have control over bringing changes to the school. Peer leaders can organize the students from the school to work with them on environmental projects, so that more students get involved and exposed to the environment while bringing about positive change. Peer leaders are the catalysts that can help steer the students toward a green future.

Last, the biggest contributor to plastic waste in schools is the school cafeteria. Most students buy food from the cafeteria. School cafeterias provide too much plastic cutlery, food packaged in plastic wrap, food in plastic containers, and single-use plastic bottles containing juice, water, and so on. Schools should use paper bags and avoid using Styrofoam and plastic packaging. To avoid using single-use plastic water bottles, schools could ask students to bring reusable water bottles. Schools also need to find a way to stop using plastic cutlery, plates, and cups. One way is for schools to buy stainless or glass tableware, or to ask students to bring reusable lunch boxes in which food can be served. Also, I have seen so many of my peers throwing plastic items in the trash bin when a recycling bin is present right next to it. To remedy this, a volunteer could stand by the bins showing which waste belongs in which bin.

Being an Eco Ambassador made me realize that plastic pollution is one of the world's most significant problems. ${ }^{3}$ I also realized that if we work together to use less plastic, it can make a big difference in the world. Individuals play a huge role in initiating changes, but schools' getting involved too will cause a much wider impact. Across the world, schools form the foundational base for students. By introducing environmental ideas, schools can influence students to the core. Exposing students to environmental issues and brainstorming solutions in their daily life will lead to a determined, motivated, and eco-friendly generation. If this generation doesn't take action and try to stop this problem, it can be the end of many things. Together we can solve this plastic pollution problem if everyone does their part in reducing the use of plastic. If we all work together to fight this plastic pollution problem, our earth, our home, will live for its full ten quadrillion years ahead of us, instead of just a few more decades.

\section{Notes}

1 For a description of the Eco Ambassador program, see https://www.edforsd.org/copy-ofeco-ambassadors

2 For a description of the World Climate Strike, see https://fridaysforfuture.org/press/

3 For information on plastic pollution of rivers and streams, see https://ourworldindata.org/ plastic-pollution 